\title{
Banking and Stock Markets in Iran: Are They Complements or Substitutes
}

\author{
Elahe Ghiasi \\ Islamic Azad University, \\ Shiraz Branch, \\ IRAN \\ estimate_set@yahoo.com
}

\author{
Reza Moosavi Mohseni ${ }^{1}$ \\ Statistic and Information \\ Bureau Governor of Fars \\ Province, Shiraz, IRAN \\ r-moosavi@,farsp.ir
}

\author{
Jalil Khodaparast Shirazi \\ Islamic Azad University, \\ Shiraz Branch, \\ IRAN \\ jks@iaushiraz.ac.ir
}

\begin{abstract}
In this study, the quarterly data from 1991:4 to 2011:3 have been used to investigate the effect of the relation between banking sector and stock market on economic growth in Iran. The break point obtained by Gregory and Hansen (1996) appears in the first quarter of 2005, which coincides with the period of the remarkable increase in oil and gas revenues. The results of Johansen test shows that higher export income in Iran decreases the substitution of banking and stock market. On the other hand, the relation between turnover and real output decreases after the break point. In addition, the relation between real output and the volatility is negative which reveals that the stock market volatility is a destructive factor for the economic growth. After the break point, considering bonds in the model does not change the results. However, it is a complementary relation between banking sectors and stock markets before the break point.
\end{abstract}

Keywords: Stock market, Banking sectors, Economic Growth, Structural break, Bonds

\section{Introduction}

There is no doubt that achieving the long-run economic growth requires optimum resource allocation and investment in the economy. To achieve this goal, it is necessary to access the vast and deep financial markets which play the role of intermediary between lenders and borrowers. Financial intermediary reduced transactions cost between savers and investors. Furthermore, it helps to decrease the problems of asymmetric information between these two groups.

When a company decides to collect financial support to develop itself or provides financial resources for a newly-established profession, it should apply for loan or issue stocks through stock market. Considering this point, it can be stated that stock market and banking sector are two main intermediaries in any country. Stock market has a key

\footnotetext{
${ }^{1}$ Corresponding author
} 
role in the development of any country's industry and business. This is the reason why governments, industry owners, and even central banks of any country pay special attention to what is happening in stock market before making any decision. Banking sector, as another major intermediary, facilitates the process of production, distribution and interchange. In the modern economy, banking sectors have a substantial role in directing the people's deposits toward investment so that their absence may leave a large part of a country's capitals useless. Thus, the role of these two financial intermediaries on economic growth is inevitable.

Except for the actual operation of credit and equity markets, Arestis et al (2001) showed that the economic growth may be affected by the interaction between these two markets. Nevertheless, most studies showed the separate effectiveness of these markets on economic growth and ignored the interaction between credit and equity markets (Cheng, 2012). Anvari Rostami and Lari Semnani (2007) investigated the relation between the investment in bank deposits and bonds with tendency toward investment (Liquidity and capitalization) in Tehran Stock Exchange. The study showed a positive correlation between tendencies toward investment in two different financial markets. The study conducted by Levine Zervos (1998) showed that financial factors are inevitable parts of the economic growth. Arestis et al (2001) found that banking sector and stock market have a great role in the economic growth. Another study by Cheng (2012) revealed that the substitution between credit and equity market is improved following financial openness.

Investigation of substitution or complimentary relation between these two markets and the effects of this relation on economic growth is vital; thus, the main objective of this paper is first, to find these relations after and before the structural break and second, the effectiveness of this relation on Iran's economic growth. But, the extent of that influence depends on whether credit and equity markets have substitutes or complement relations. However, on one hand, when the company's stocks are issued, the company lowers its application for loan. This shows that credit and equity markets are substitutes. On the other hand, development of stock markets may increase the non-lending businesses of the banks. Therefore, banks have developed along with stock markets in such a manner that both lead to economic growth which shows that both are complements each other. The researchers followed Boyed and Smith (1996), Demirguckunt and Maksimovic (1996) and Cheng (2012) to investigate the interaction between credit and equity markets by referring to the relation between economic growth and the debt-to-equity ratio. The economy develops beside increases (decreases) in the debt-toequity ratio supporting the assertion that the two sources of finance are complements (substitutes) (Cheng, 2012).

Moreover, this study is going to find the mentioned relation and its effect on economic growth under the structural break. Many variables undergo implicit events that will affect and change their time series. These changes may be due to events such as war, financial crisis or remarkable changes in government policies. The process in which a time series under investigation goes out of its usual pattern is called "structural break". Two different models can be used to analyze such time series before and after the break point; but, this method is not appropriate to predict the overall time series (Hamilton, 1994). The researchers employed the Gregory and Hansen's test to identify the break point. This test not only helps to investigate the long-run relation between 
financial institutions and economic growth under the structural break but also determines the break point endogenously.

Patrick (1996) states the causality between financial development and economic growth through terms such as "supply-leading" and "demand- following". Supplyleading happens when the development of capital market and financial services leads to economic growth. Demand-following is when economic growth leads to more demands for financial services. If the results show mutual relationships between financial markets and economic growth in long-run, it can be stated that supply-leading and demandfollowing are symbiotic phenomena. It should be noted that in this study these terms are used for the causality.

In this study, quarterly data from 1991:4 to 2011:3 have been used to investigate the effect of relation between banking and stock markets on economic growth in Iran. The data was extracted from Iran central bank website ${ }^{2}$ and Tehran Stock Exchange . $^{3}$

\section{Structure of the model}

\subsection{Model Specification}

The researchers employed a vector auto regressive (VAR) framework to investigate the effect of long-run relation between the two financial markets on economic growth before and after the break point:

$$
Z_{t}=B_{1} Z_{t-1}+B_{2} Z_{t-2}+\ldots+B_{p} Z_{t-p}+\varepsilon_{t}
$$

This equation $Z_{t}=\left(L R G D P_{t}, D E-\text { ratio }_{t}, \text { Turnover }_{t}, \text { Volatility }_{t}\right)^{\prime}$ is a four vector of endogenous variables, where LRGDP (logarithm real gross domestic product) shows economic growth. DE-ratio (Debt-to-equity ratio) is the index which is used to show the relation between credit and equity markets which is calculated through the following equation:

$$
D E-\text { ratio }=\frac{0.5 \times\left(\frac{M 2_{t}}{C P I_{t}}+\frac{M 2_{t-1}}{C P I_{t-1}}\right) /\left(\frac{G D P_{t}}{\operatorname{avg}\left(C P I_{t}\right)}\right)}{0.5 \times\left(\frac{M V_{t}}{C P I_{t}}+\frac{M V_{t-1}}{C P I_{t-1}}\right) /\left(\frac{G D P_{t}}{\operatorname{avg}\left(C P I_{t}\right)}\right)}
$$

Where $M V_{t}$ shows the amount of stock market capitalization at the end of the quarter $(\mathrm{t})$, and $\operatorname{avg}\left(C P I_{t}\right)$ is the average of the beginning and ending consumer price indexes (CPIs) for the quarter $t$. Turnover and volatility are two control indices that are entered into the equation along with the main variable. Stock market volatility is calculated through an eight-quarter moving standard deviation of the end-of-quarter change in stock market price, and turnover is calculated by the following equation:

$$
\text { TURNOVER }=\left(\frac{\text { Value }_{t}}{\operatorname{avg}\left(C P I_{t}\right)}\right) /\left[0.5 \times\left(\frac{M V_{t}}{C P I_{t}}+\frac{M V_{t-1}}{C P I_{t-1}}\right)\right]
$$

In this equation Value $t$ is the total value traded at the end of the quarter $(\mathrm{t})$.

\footnotetext{
${ }^{2}$ www.cbi.ir

${ }^{3}$ www.tse.ir
} 


\subsection{Unit root with structural break: Zivot and Andrews Test}

Non-stationary feature of time series produces spurious regression and this regression leads the results to be non-trustable. This study is going to investigate the unit root under the structural break. That is why the researchers used Zivot and Andrews test:

$$
\begin{array}{ll}
A: & y_{t}=\mu+\theta D U_{t}\left(T_{b}\right)+\beta t+\alpha y_{t-1}+\sum_{j=1}^{k} c \Delta y_{t-j}+e_{t} \\
B: & y_{t}=\mu+\beta t+\gamma D T_{t}\left(T_{b}\right)+\alpha y_{t-1}+\sum_{j=1}^{k} c \Delta y_{t-j}+e_{t} \\
C: & y_{t}=\mu+\theta D U_{t}\left(T_{b}\right)+\beta t+\gamma D T_{t}\left(T_{b}\right)+\alpha y_{t-1}+\sum_{j=1}^{k} c \Delta y_{t-j}+e_{t}
\end{array}
$$

Model A shows the changes in intercept while model B shows the changes in slope and model $\mathrm{C}$ shows coincident the changes in intercept and slope. These models are estimated through OLS. $D U_{t}$ and $D T_{t}$ are also virtual variables that are defined as:

$$
\begin{aligned}
& D U_{t}= \begin{cases}1 & t>T_{b} \\
0 & t \leq T_{b}\end{cases} \\
& D T_{t}= \begin{cases}t-T_{b} & t>T_{b} \\
0 & t \leq T_{b}\end{cases}
\end{aligned}
$$

Where $T_{b}$ is the time for structural break. (Zivot and Andrews, 1992)

\subsection{Cointegration with structural break: Gregory and Hansen, 1996}

Gregory and Hansen's test identified the break point of the investigated data endogenously. Based on this test, one of the following models will be used to make a pattern for structural break:

$$
\begin{aligned}
& y_{1 t}=\theta_{0}+\theta_{1} D_{t b}+\beta y_{2 t}+e_{t} \\
& y_{1 t}=\theta_{0}+\theta_{1} D_{t b}+\beta y_{2 t}+\gamma t+e_{t} \\
& y_{1 t}=\theta_{0}+\theta_{1} D_{t b}+\beta_{1} y_{2 t}+\beta_{2} y_{2 t} D_{t b}+e_{t}
\end{aligned}
$$

Equation 9 is known as the model of change in level, equation 10 is known as the model of change in level along with the trend and the third equation is defined as the model of change in regime. $D_{t b}$ is also a virtual variable that it is defined as follows: 


$$
D_{t b}=\left\{\begin{array}{lc}
1 & t>T \lambda \\
0 & t \leq T \lambda
\end{array}\right.
$$

in which $\lambda=\frac{T_{B}}{T}, T$ and $T_{B}$ show the total sample size and the data when the structural breaks occurred, respectively.

\subsection{Johansen cointegration test}

When the break point is identified through Gregory and Hansen's test, equation 1 is applied in a vector autoregressive (VAR) framework, proposed by Johansen (1988) and Johansen and Juselius (1990) to investigate the effect of long-run relation between these two financial markets on economic growth before and after the structural break.

Therefore, equation 1 is re-written as follows:

$$
\Delta Z_{t}=\pi Z_{t-1}+\sum_{i=1}^{p-1} \pi_{i} \Delta Z_{t-i}+\varepsilon_{t}
$$

where $\pi=-\left(I-\sum_{i=1}^{p} B_{i}\right)$ and $\pi_{i}=-\sum_{j=i+1}^{p} B_{j}$. The rank of $\pi$ shows the number of independent cointegrating vectors (Cheng, 2012). To find the optimal lag, the SchwarzBayesian and Akaike Information Criteria are employed.

\subsection{Toda and Yamamoto's Casualty test}

Toda and Yamamoto (1995) suggested an estimated simple method of modified vector autoregressive model to investigate Granger's casualty. They justified that this method is even valid when there is a cointegration relation among variables. In this method, first, the number of optimal lags $(\mathrm{k})$ of the vector autoregressive model and then maximum degree of perpetuity $\left(d_{\max }\right)$ will be determined and a vector autoregressive model with number of lags $\left(k+d_{\max }\right)$ will be specified. However, the process of selecting lags will be valid if $k \geq d_{\max }$. The applied statistics of the test is Wald statistics with a degree of freedom equal to the number of null limitations; therefore, the following equation will be tested in the current study:

$$
\left[\begin{array}{l}
\text { volatility }_{t} \\
\text { turnover }_{t} \\
D E-\text { ratio }_{t} \\
\text { LRGDP }_{t}
\end{array}\right]=A_{0}+A_{1}\left[\begin{array}{l}
\text { volatility }_{t-1} \\
\text { turnover }_{t-1} \\
D E-\text { ratio }_{t-1} \\
\text { LRGDP }_{t-1}
\end{array}\right]+\ldots+A_{n}\left[\begin{array}{l}
\text { volatility }_{t-k} \\
\text { turnover }_{t-k} \\
D E-\text { ratio }_{t-k} \\
L R G D P_{t-k}
\end{array}\right]+\left[\begin{array}{l}
e_{\text {volatility }, t} \\
e_{\text {turnover }, t} \\
e_{D E-\text { ratio, }, t} \\
e_{L R G D P, t}
\end{array}\right]
$$

where $e_{t}$ shows vector of error terms and A shows Vector of coefficients.

\section{Empirical results}

In this section interested stationary and cointegration tests will be used to investigate the effect of the relation between stock market and the banking sector on the economic growth. 


\subsection{Stationary test}

Before trying to identify the long-run relation, we need to determine the degree of cointegration in our systems. Zivot and Andrews (1992) believed that the existence of structural breaks may lead to wrong results in the traditional tests when they rejected the null hypothesis of unit root. Since variables of macroeconomic in Iran are exposed to several structural breaks, it is possible that traditional tests such as ADF and PP have bias toward fail to reject the null of unit root. Therefore, Zivot and Andrews unit root test was applied for the current study. Zivot and Andrews test determines the time of structural break endogenously that is against Perron test in which the time of structural break is considered as pre-determined.

The results obtained from Gauss software showed that LRGDP and Turnover had a trend while time series of the other two variables did not have any trend. Therefore, model A was used to investigate the stationary of variables as volatility and DE-ratio while model $\mathrm{C}$ - which is more comprehensive in comparison with the other two models - was used for variables as LRGDP and Turnover. The results of these tests have been shown through Table $1 .^{4}$

As depicted in tables, all variables of the model are integrated of order one in level by one endogenous structural break.

Table 1. ZA unit root test

\begin{tabular}{|c|c|c|c|c|c|}
\hline \multirow{2}{*}{ Variables } & \multirow{2}{*}{ Break } & \multirow{2}{*}{ Possible reasons for break } & \multirow{2}{*}{ Model } & \multicolumn{2}{|c|}{ ZA } \\
\hline & & & & Level & 1 st Diff \\
\hline$L R G D P$ & 2003:1 & $\begin{array}{c}\text { Unification of the } \\
\text { exchange rate, the } \\
\text { increase in oil world price, } \\
\text { financial openness: } \\
\text { License for private } \\
\text { insurance }\end{array}$ & $\mathrm{C}$ & $-3 / 666517$ & $-6 / 825852$ \\
\hline$D E-$ ratio & $1997: 3$ & $\begin{array}{l}\text { Political developments and } \\
\text { presidential elections in the } \\
\text { country }\end{array}$ & A & $-4 / 708241$ & $-6 / 229540$ \\
\hline Turnover & $2002: 3$ & $\begin{array}{l}\text { Unification of the } \\
\text { exchange rate, the } \\
\text { increase in oil world price, } \\
\text { financial openness: } \\
\text { License for private } \\
\text { insurance }\end{array}$ & $\mathrm{C}$ & $-3 / 828892$ & $-8 / 103299$ \\
\hline Volatility & 2006:1 & $\begin{array}{c}\text { Broad participation of } \\
\text { nongovernment sector, the } \\
\text { increase in oil world price }\end{array}$ & A & $-2 / 755829$ & $-6 / 264846$ \\
\hline & & $\begin{array}{l}\text { ritical value for } \mathrm{A} \text { model of } \\
\text { ritical value for } \mathrm{C} \text { model of }\end{array}$ & $\begin{array}{l}\text { A te: } \\
\text { tes }\end{array}$ & & \\
\hline
\end{tabular}

${ }^{4}$ These models have been introduced in section (2.2). 


\subsection{Cointegration with structural break: Gregory \& Hansen Test}

Engel and Grenger (1987) suggested Cointegration method for non-stationary variables. However, this method may lead to wrong results under the existence of structural break. Gregory and Hansen (1996) modified Engel and Grenger's test to allow it to be used with structural breaks. In this test, null hypothesis will be tested against alternative hypothesis with a structural break. Determining the break point endogenously is one of the main benefits of this test. Therefore, this test makes it possible not only to investigate the long-run relation among variables under the structural break but also to identify the break point of data.

Table 2. Gregory and Hansen cointegration test

\begin{tabular}{|c|c|c|c|}
\hline Test statistics & Critical value & Breakpoint & $5 \%$ critical value \\
\hline Phillips(zt) & $-8 / 0331914$ & $2005: 1$ & $-5 / 57$ \\
\hline
\end{tabular}

Table 2 reveals a long-run relation among interested variables with considering a breakpoint. As depicted in Table 2, the break point obtained by Gregory and Hansen (1996) appears in the first quarter of 2005, which coincides with the period of remarkable increase in income by means of the export of oil and gas. This year was an unstable year for the Persian Gulf; moreover, energy demand in the world and especially in China experienced a rapid growth; therefore, the world price of oil increased. Consequently, OPEC increased its oil production. It is clear that oil income is directly under the influence of two factors including world price of oil and oil export quantity. The outcome of the changes in these two variables in 2005 led to a remarkable increase in oil income. This increase itself resulted in a considerable commercial balance (Central Bank of the Islamic Republic of Iran, economic policies and Reviews office, 2005).

\subsection{Johansen cointegration test}

After identifying the breakpoint and finding that all variables are integrated of order one, the Johansen cointegration test can be used to investigate whether long-run relation among variables remain unchanged before and after the structural break. Table 3 shows the results of the trace and rank tests to determine the number of cointegration vectors before the break point.

Calculation done for both before and after the break point determined two lags as an appropriate lag structure for the model.

Table 3. Trace and Rank tests (Before breakpoint)

\begin{tabular}{|c|c|c|c|c|c|}
\hline \multicolumn{2}{|c|}{ hypothesis } & \multicolumn{2}{c|}{ Trace test } & \multicolumn{2}{c|}{ Rank test } \\
\hline null & alternative & Critical value & $\begin{array}{c}5 \% \text { critical } \\
\text { value }\end{array}$ & $\begin{array}{c}\text { Critical } \\
\text { value }\end{array}$ & $\begin{array}{c}5 \% \text { critical } \\
\text { value }\end{array}$ \\
\hline$r=0$ & $r \geq 1$ & $70 / 03$ & $47 / 85$ & $35 / 92$ & $27 / 58$ \\
\hline$r \leq 1$ & $r \geq 2$ & $34 / 11$ & $29 / 79$ & $23 / 81$ & $21 / 13$ \\
\hline$r \leq 2$ & $r \geq 3$ & $10 / 29$ & $15 / 49$ & $7 / 49$ & $14 / 26$ \\
\hline$r \leq 3$ & $r \geq 4$ & $2 / 80$ & $3 / 84$ & $2 / 80$ & $3 / 84$ \\
\hline
\end{tabular}

On the other hand, based on the results of Johansen test there are two co integration vectors before the break point. 
E. Ghiasi - R. M. Mohseni - J. K. Shirazi 6/1 (2014) 7-20

Table 4. Estimated cointegrating vector (Before breakpoint)

\begin{tabular}{|c|c|c|}
\hline variable & cointegrating vector & $\begin{array}{c}\text { Normalized cointegrating } \\
\text { vector and Coefficient } \\
\text { (t-statistics) }\end{array}$ \\
\hline LRGDP & $-0 / 481451$ & 1 \\
\hline DE-ratio & $0 / 267473$ & $(-4 / 50)-0 / 55$ \\
\hline Turnover & $-155 / 1667$ & $(5 / 83) 322 / 28$ \\
\hline Volatility & $0 / 003274$ & $(-5 / 98)-0 / 006$ \\
\hline
\end{tabular}

Table 4 shows negative relation between LRGDP and DE-ratio before the break point. This relation reveals that debt-to-equity ratio tends to decline when economic growth increases in Iran which shows that these two financial sources (stock market and banking sector) being substitutive in Iran. This is congruent with the study done by Demirguc-Kunt and Maksimovic(1996). They believed that banks are fearful of stock market since stock markets may limit banks' activities in many developing countries. The number in parenthesis shows $t$ for each indicator.

The researchers conclude that the coefficient of Turnover shows a positive relation between Turnover and LRGDP before the break time. This relation indicates that stock markets will help real economic growth by providing liquidity and allocating efficient resources. In fact, stock market helps economic growth in at least two ways. First, this market makes it possible for investors to trade their properties with lower risks when they need to alter financial portfolios with low transaction costs. Second, stock market provides an external mechanism for investors and entrepreneurs to improve efficiency of financial intermediation (Cheng, 2012). Moreover, the following table shows the negative relation between volatility and LRGDP. As the researchers expected, instability in stock market prevents sufficient investment and consequently, lowers the economic growth.

Table 5. Trace and Rank tests(After breakpoint)

\begin{tabular}{|c|c|c|c|c|c|}
\hline \multicolumn{2}{|c|}{ hypothesis } & \multicolumn{2}{c|}{ Trace test } & \multicolumn{2}{c|}{ Rank test } \\
\hline Null & alternative & Critical value & $\begin{array}{c}5 \% \text { critical } \\
\text { value }\end{array}$ & $\begin{array}{c}\text { Critical } \\
\text { value }\end{array}$ & $\begin{array}{c}5 \% \text { critical } \\
\text { value }\end{array}$ \\
\hline$r=0$ & $r \geq 1$ & $72 / 90$ & $47 / 85$ & $54 / 27$ & $27 / 58$ \\
\hline$r \leq 1$ & $r \geq 2$ & $18 / 63$ & $29 / 79$ & $11 / 58$ & $21 / 13$ \\
\hline$r \leq 2$ & $r \geq 3$ & $7 / 04$ & $15 / 49$ & $6 / 30$ & $14 / 26$ \\
\hline$r \leq 3$ & $r \geq 4$ & $0 / 74$ & $3 / 84$ & $0 / 74$ & $3 / 84$ \\
\hline
\end{tabular}

Table 6 shows that the relation between DE-ratio, Turnover and volatility to LRGDP have been decreased after the breakpoint without any changes in the sign of the coefficients. The result of the relation between LRGDP and DE-ratio reveals that higher export decreases the substitution between credit and equity markets. In fact, it can be stated that higher export helps both markets to increase their resources without any need to compete directly with each other. 
E. Ghiasi - R. M. Mohseni - J. K. Shirazi 6/1 (2014) 7-20

Table 6. Estimated cointegrating vector (After breakpoint)

\begin{tabular}{|c|c|c|}
\hline variable & cointegrating vector & $\begin{array}{c}\text { Normalized cointegrating } \\
\text { vector and Coefficient } \\
\text { (t-statistics) }\end{array}$ \\
\hline LRGDP & $-90 / 05707$ & 1 \\
\hline DE-ratio & $5 / 629302$ & $(-17 / 79)-0 / 06$ \\
\hline Turnover & $-33 / 21928$ & $(4 / 26) 0 / 36$ \\
\hline Volatility & $0 / 001750$ & $(-9 / 65)-1 / 94 e^{-5}$ \\
\hline
\end{tabular}

Decrease in relation between turnover and LRGDP after the break point shows that excessive liquidity may attract noise traders and prevent the increase of real production of the country as before, although liquidity helps economic growth.

The relation between volatility and LRGDP after break time is trivial; however, it shows that instability in stock market is a destructive factor for the economic growth.

\subsection{The role of government's bonds}

This section will discuss whether bonds will affect the results of DE-ratio in this research. This instrument has been applied in Iran since 1994 in order to provide financial sources for qualified projects. This instrument was effective and welcomed (central bank of the Islamic Republic of Iran, credit office). The existence of bonds as a new choice for investors and savers may affect the relation between banking sectors and stock markets. This confirms the role of bonds on the overall financial system.

In this study the ratio of bonds issued by government to GDP was used as an indicator of bond development. The related data was collected from the central bank of the Islamic Republic of Iran. The first bonds were issued at September 23 in 1994; therefore, the relevant tests in this study with respect to bonds are repeated from the last quarter of 1994. Firstly, the researchers investigated the stationary of Bond.

Table 7. ZA unit root test

\begin{tabular}{|l|c|c|c|c|}
\hline \multirow{2}{*}{ Variable } & Break & \multirow{2}{*}{ Model } & \multicolumn{2}{|c|}{ ZA } \\
\cline { 4 - 5 } Bond & $2000: 3$ & A & $-3 / 455972$ & $-6 / 159393$ \\
\hline \multirow{2}{*}{$5 \%$ critical value for A model of ZA test: $-4 / 93$} \\
\hline
\end{tabular}

As depicted in Table 7, Bond variable is I(1). More specifically, Johansen test is used to investigate the role of Bond in long-run relation among variables. As it was found out for models without Bond, calculations done before and after the break point determined two lags as appropriate lag structure for the model. 
E. Ghiasi - R. M. Mohseni - J. K. Shirazi 6/1 (2014) 7-20

Table 8. Trace and Rank tests (Before break point with adding bond)

\begin{tabular}{|c|c|c|c|c|c|}
\hline \multicolumn{2}{|c|}{ hypothesis } & \multicolumn{2}{c|}{ Trace test } & \multicolumn{2}{c|}{ Rank test } \\
\hline Null & alternative & Critical value & $\begin{array}{c}5 \% \text { critical } \\
\text { value }\end{array}$ & Critical value & $\begin{array}{c}5 \% \text { critical } \\
\text { value }\end{array}$ \\
\hline$r=0$ & $r \geq 1$ & $149 / 31$ & $69 / 81$ & $82 / 02$ & $33 / 87$ \\
\hline$r \leq 1$ & $r \geq 2$ & $67 / 28$ & $47 / 85$ & $33 / 67$ & $27 / 58$ \\
\hline$r \leq 2$ & $r \geq 3$ & $33 / 61$ & $29 / 79$ & $22 / 91$ & $21 / 13$ \\
\hline$r \leq 3$ & $r \geq 4$ & $10 / 69$ & $15 / 49$ & $8 / 63$ & $14 / 26$ \\
\hline$r \leq 4$ & $r \geq 5$ & $2 / 05$ & $3 / 84$ & $2 / 05$ & $3 / 84$ \\
\hline
\end{tabular}

Table 9. Trace and Rank tests (After break point with adding bond)

\begin{tabular}{|c|c|c|c|c|c|}
\hline \multicolumn{2}{|c|}{ hypothesis } & \multicolumn{2}{c|}{ Trace test } & \multicolumn{2}{c|}{ Rank test } \\
\hline Null & alternative & Critical value & $\begin{array}{c}5 \% \text { critical } \\
\text { value }\end{array}$ & Critical value & $\begin{array}{c}5 \% \text { critical } \\
\text { value }\end{array}$ \\
\hline$r=0$ & $r \geq 1$ & $148 / 32$ & $69 / 81$ & $65 / 87$ & $33 / 87$ \\
\hline$r \leq 1$ & $r \geq 2$ & $82 / 45$ & $47 / 85$ & $54 / 15$ & $27 / 58$ \\
\hline$r \leq 2$ & $r \geq 3$ & $28 / 30$ & $29 / 79$ & $16 / 81$ & $21 / 13$ \\
\hline$r \leq 3$ & $r \geq 4$ & $11 / 49$ & $15 / 49$ & $10 / 85$ & $14 / 26$ \\
\hline$r \leq 4$ & $r \geq 5$ & $0 / 64$ & $3 / 84$ & $0 / 64$ & $3 / 84$ \\
\hline
\end{tabular}

It can be seen from tables 8 and 9 , that there are three cointegration vectors before the break point and two after the break point.

Table 10. Estimated cointegrating vector (Before break point with adding bond)

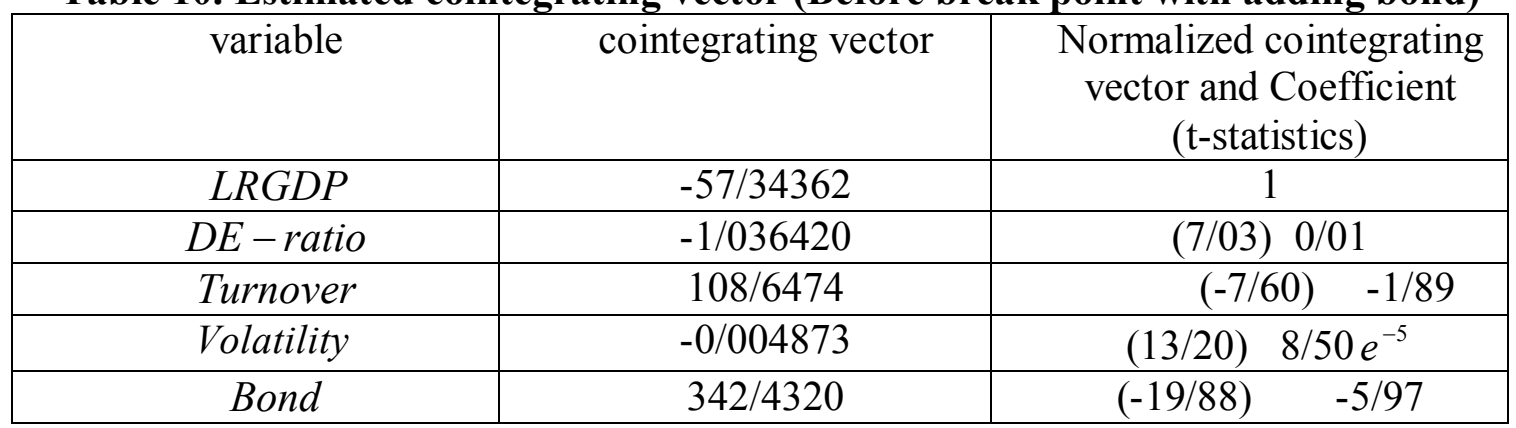

In comparison with stock markets, bond market is a less-developed market in Iran. Considering tables 10 and 11 , it can be stated that the existence of bonds as another option available to choose may threaten and limit the activities of banking sector and stock market. For this reason, they prefer to develop and progress along each other instead of competing. But, higher export revenue and more extensive resources decreased sensitivity of banks and stock market to bonds; therefore, they started competing with each other to attract more resources although it will not be a severe competition due to more extensive and wider resources. 
E. Ghiasi - R. M. Mohseni - J. K. Shirazi 6/1 (2014) 7-20

Table 11. Estimated cointegrating vector (After break point with adding bond)

\begin{tabular}{|c|c|c|}
\hline variable & cointegrating vector & $\begin{array}{c}\text { Normalized cointegrating } \\
\text { vector and Coefficient } \\
\text { (t-statistics) }\end{array}$ \\
\hline LRGDP & $-63 / 00891$ & 1 \\
\hline DE-ratio & $2 / 736838$ & $(-8 / 34)-0 / 04$ \\
\hline Turnover & $86 / 16050$ & $(-7 / 83)-1 / 36$ \\
\hline Volatility & $0 / 000736$ & $(-3 / 22)-1 / 17 e^{-5}$ \\
\hline Bond & $10 / 64471$ & $(-4 / 50)-0 / 16$ \\
\hline
\end{tabular}

\subsection{Granger causality: Toda and Yamamoto test}

After finding long-run impact of the relation among financial institutes on the economic growth, the researchers investigate the long-run causality among variables in a modified vector autoregressive (VAR) framework.

In this method, first, the number of optimal lags $(\mathrm{k})$ of the vector autoregressive model and then maximum degree of perpetuity $\left(d_{\max }\right)$ will be determined and a vector autoregressive model with number of lags $\left(k+d_{\max }\right)$ will be specified.

As stated in previous sections, both calculations conducted before and after the break point determined two lags $(\mathrm{k}=2)$ as appropriate lag structure for the model. Then a vector autoregressive model with a number of lags $\left(k+d_{\max }=3\right)$ will be specified. The following equation is estimated for four-variable regression:

$$
\begin{aligned}
& {\left[\begin{array}{l}
\text { volatility }_{t} \\
\text { turnover }_{t} \\
\text { DE-ratio } \\
\text { LRGDP }_{t}
\end{array}\right]=\left[\begin{array}{l}
a_{10} \\
a_{20} \\
a_{30} \\
a_{40}
\end{array}\right]+\left[\begin{array}{llll}
a_{11}^{1} & a_{12}^{1} & a_{13}^{1} & a_{14}^{1} \\
a_{21}^{1} & a_{22}^{1} & a_{23}^{1} & a_{24}^{1} \\
a_{31}^{1} & a_{32}^{1} & a_{33}^{1} & a_{34}^{1} \\
a_{41}^{1} & a_{42}^{1} & a_{43}^{1} & a_{44}^{1}
\end{array}\right]\left[\begin{array}{l}
\text { volatility }_{t-1} \\
\text { turnover }_{t-1} \\
D E-\text { ratio }_{t-1} \\
\text { LRGD }_{t-1}
\end{array}\right]+\left[\begin{array}{llll}
a_{11}^{2} & a_{12}^{2} & a_{13}^{2} & a_{14}^{2} \\
a_{21}^{2} & a_{22}^{2} & a_{23}^{2} & a_{24}^{2} \\
a_{31}^{2} & a_{32}^{2} & a_{33}^{2} & a_{34}^{2} \\
a_{41}^{2} & a_{42}^{2} & a_{43}^{2} & a_{44}^{2}
\end{array}\right]\left[\begin{array}{l}
\text { volatility }_{t-2} \\
\text { turnover }_{t-2} \\
\text { DE-ratio } \\
t-2 \\
\text { LRGDP }_{t-2}
\end{array}\right]} \\
& +\left[\begin{array}{cccc}
a_{11}^{3} & a_{12}^{3} & a_{13}^{3} & a_{14}^{3} \\
a_{21}^{3} & a_{22}^{3} & a_{23}^{3} & a_{24}^{3} \\
a_{31}^{3} & a_{32}^{3} & a_{33}^{3} & a_{34}^{3} \\
a_{41}^{3} & a_{42}^{3} & a_{43}^{3} & a_{44}^{3}
\end{array}\right]\left[\begin{array}{l}
\text { volatility }_{t-3} \\
\text { turnover }_{t-3} \\
D E-\text { ratio }_{t-3} \\
\text { LRGDP }_{t-3}
\end{array}\right]+\left[\begin{array}{l}
e_{\text {volatility,t }} \\
e_{\text {turnover }, t} \\
e_{D E-\text { ratio }, t} \\
e_{L R G D P, t}
\end{array}\right]
\end{aligned}
$$

After estimating this equation system through OLS method, the following hypotheses are tested to investigate the relation among variables before and after the break point:

$$
\begin{aligned}
& a_{41}^{1}=a_{41}^{2}=a_{41}^{3}=0 \\
& a_{42}^{1}=a_{42}^{2}=a_{42}^{3}=0 \\
& a_{43}^{1}=a_{43}^{2}=a_{43}^{3}=0 \\
& a_{34}^{1}=a_{34}^{2}=a_{34}^{3}=0 \\
& a_{24}^{1}=a_{24}^{2}=a_{24}^{3}=0 \\
& a_{14}^{1}=a_{14}^{2}=a_{14}^{3}=0
\end{aligned}
$$


E. Ghiasi - R. M. Mohseni - J. K. Shirazi 6/1 (2014) 7-20

Table 12. Causality test

\begin{tabular}{|c|c|c|c|c|c|}
\hline Null hypothesis and & \multicolumn{3}{|c|}{ Before break point } & \multicolumn{2}{|c|}{ After break point } \\
\hline Null hypothesis & $\begin{array}{l}\text { Degrees of } \\
\text { freedom }\end{array}$ & $\chi^{2}$-statistics & Probability & $\chi^{2}$-statistics & Probability \\
\hline $\begin{array}{c}\text { DE-ratio } \\
\text { does not Granger Cause } \\
\text { LRGDP }\end{array}$ & 3 & $7 / 031430$ & 0/0709 & $13 / 85482$ & $0 / 0031$ \\
\hline $\begin{array}{c}\text { LRGDP } \\
\text { does not Granger Cause } \\
\text { DE-ratio }\end{array}$ & 3 & $8 / 117345$ & $0 / 0436$ & $1 / 480959$ & $0 / 6867$ \\
\hline $\begin{array}{c}\text { Volatility } \\
\text { does not Granger Cause } \\
\text { LRGDP }\end{array}$ & 3 & $0 / 369272$ & $0 / 9465$ & $21 / 24937$ & $0 / 0001$ \\
\hline $\begin{array}{c}\text { LRGDP } \\
\text { does not Granger Cause } \\
\text { Volatility }\end{array}$ & 3 & $0 / 922432$ & $0 / 82$ & $4 / 665251$ & $0 / 198$ \\
\hline $\begin{array}{c}\text { Turnover } \\
\text { does not Granger Cause } \\
\text { LRGDP }\end{array}$ & 3 & $3 / 180926$ & $0 / 3646$ & $5 / 177199$ & $0 / 1593$ \\
\hline $\begin{array}{c}\text { LRGDP } \\
\text { does not Granger Cause } \\
\text { Turnover } \\
\end{array}$ & 3 & $4 / 767958$ & $0 / 1896$ & $2 / 307944$ & $0 / 511$ \\
\hline & & 2 & & & \\
\hline
\end{tabular}

Table 12 shows a mutual causality relation between DE-ratio and LRGDP in 10\% level. In other words, it can be stated that supply-leading and demand-following before the breakpoint are symbiotic phenomena in this level. However, a one-way causality relation was found from LRGDP to DE-ratio in 5\% level. This table shows no causality relation before the breakpoint from turnover and volatility to LRGDP and from LRGDP to turnover and volatility in 5\% and 10\% level, respectively. Due to this table, there are causality relations from DE-ratio and volatility to LRGDP after the break point in both $5 \%$ and $10 \%$ level, respectively. Furthermore, this table reveals no causality relation after the break point from LRGDP to DE-ratio, turnover and volatility and from turnover to LRGDP.

\section{Conclusion}

This study used the quarterly data from 1991:4 to 2011:3 to investigate the impact of relation between banking sector and stock market on the economic growth in Iran emphasizing on the possibility of structural break. Some interesting findings are as follow: First, the break point obtained by Gregory and Hansen (1996) appears in the first quarter of 2005, which coincides with the period of remarkable increase in income by means of the export of oil and gas. Second, higher export revenue in Iran decreased the substitution of banking sector and stock market that shows less competition between these two markets to achieve limited resources. Third, the relation between turnover and real output decreased after the break point. This shows that excessive liquidity may attract noise traders and prevent the increase of real output of the country as before although liquidity helps the economic growth. Fourth, the relation between volatility 
and real output is negative. This point shows that instability in stock market is a destructive factor for the economic growth. Fifth, the results remained unchanged after the break point considering the role of government bonds. However, there is a complementary between stock market and banking sector before the breakpoint. With respect to the findings, it can be stated that whatever the financial resources moved from banking sector toward stock market, increased the economic growth in Iran. In other words, this shows that stock market had a better function in efficient allocation of resources for investment. Finally, the Toda and Yamamoto test in a four-variable model shows the existence of a mutual causality relation between DE-ratio and LRGDP in $10 \%$ level before the break point. This mutual causality relation changed to a one-way causality relation from DE-ratio to LRGDP after break point.

\section{References}

Arestis P. Demetriades PO. Luintel KB. 2001. Financial development and economic growth: the role of stock markets. Journal of Money, Credit, and Banking, 33: 16-41.

Boyd J H. Prescott EC. 1986. Financial intermediary-coalitions. Journal of Economics Theory, 38: $32-211$.

Boyd J. Smith B. 1996. The coevolution of the real and financial sectors in the growth process. World Bank Economic Review, 10: 371-396.

Central Bank of the Islamic Republic of Iran, 2005, economic policies and Reviews office.

Chenery HB. Strout AM. 1966. Foreign assistance and economic development. American Economic Review, 56: 679-733.

Cheng SY. 2012. Substitution or complementary effects between banking and stock markets: evidence from financial openness in Taiwan. Journal of International Financial Markets, Institutions \&Money, 22: 508-520.

Cheng X. Degryse H. 2010. The impact of banks and non-banks fianacial institution on local economic growth in China. Journal of Financial Services Research, 37: 179-199.

Chiarella C. Flaschel P. Hartmann F. Proano CR. 2012. Stock market booms, endogenous credit creation and the implications of broad and narrow banking for macroeconomic stability. Journal of Economic Behavior \& Organization, $1-14$.

Demirguc-Kunt A. Levine R. 2001. Financial structure and economic growth. Cambridge, Massachusetts, The MIT Press.

Demirguc-Kunt A. Maksimovic V. 1996. Stock market development and financing choices offirms. World Bank Economic Review, 10: 341-369.

Dow J. Gorton G. 1997. Stock market efficiency and economic efficiency: is there a connection? Journal of Finance, 52: 1087-1129.

Eleswarapu V. Venkataraman K. 2002. The impact of legal and political institutions on equity trading costs: a cross-country analysis, Working paper

Engle RF. Granger CWJ. 1987. Cointegration and error correction: representation, estimation and testing. Econometrica, 55: 76-251.

Granger CWJ. 1969. Investigating casual relation by econometric models and cross spectral methods. Econometrica, 37: 424-438. 
Gregory AW. Hansen BE. 1996. Residual-based tests for cointegration inm with regime shifts. Journal of Econometrics, 70: 99-126.

Hamilton JD. 1954. Time series analysis. New Jersey: Princeton University Press.

Johansen S. 1988. Statistical analysis of cointegration vectors. Journal of Economic Dynamics and Control, 12: 54-231.

Johansen S. Juselius K. 1990. Maximum likelihood estimation and inference on cointegration with applications to the demand for money. Oxford Bulletin of Economics and Statistics, 52: 169-210.

King RG. Levine R. 1993. Finance and growth: schumpeter might be right. The Quarterly Journal of Economics, 108: 717-737.

Kuznets S. 1966. Modern economic growth: rate structure and spread. New Haven CT, Yale 18 University Press.

La Porta R. Lopez-de-Silanes F. Shleifer A. Vishny R. 1998. Law and finance. Journal of Political Economy, 106: 55-1113.

Levine R. Zervos S. 1998. Stock markets, banks, and economic growth. The American Economic Review, 88: 537-558.

Mishkin FS. 2004. The economics of money, banking, and financial markets. Seventh Edition.Columbia University Press.

Osterwald-Lenum M. 1992. A note with quantiles of the asymptotic distribution of the maximum likelihood cointegration rank test statistics. Oxford Bulletin of Economics and Statistics, 54: 461-472.

Patrick H. 1966. Financial development and economic growth in underdeveloped countries. Economic Development and Cultural Change, 14: 174-189.

Rousseau PL. Wachtel P. 1998. Financial intermediation and economic performance: historical evidence from five industrialized economies. Journal of Money, Credit and Banking, 30: 657-678.

Rousseau PL. Xiao S. 2007. Banks, stock markets, and China's 'great leap forward'. Emerging Markets Review, 8: 206-217.

Schumpeter JA. 1911. The theory of economic development. Harvard University Press.

Schwert GW. 1989. Why does stock market volatility change over time? The Journal of Finance, 44: 1115-1153.

Shaw E.1973. Financial deepening in economic development. NewYork: Oxford University Press.

Sims G. 1972. Money, income and causality. American Economic Review, 62: 540-552.

Zivot E. Andrews DWK. 1992. Further evidence on the great crash, the oil-price shock and the unit-root hypothesis. Journal of Business \& Economic Statistics, 10: 251-270. 